\title{
Shell alterations in limpets as putative biomarkers for multi-impacted coastal areas ${ }^{2 \pi}$
}

\author{
Felipe Nincao Begliomini a , Daniele Claudino Maciel ${ }^{b}$, Sérgio Mendonça de Almeida ${ }^{\text {c, d }}$, \\ Denis Moledo Abessa ${ }^{e}$, Luciane Alves Maranho ${ }^{a}$, Camilo Seabra Pereira ${ }^{a}$, \\ Gilvan Takeshi Yogui ${ }^{\mathrm{b}}$, Eliete Zanardi-Lamardo ${ }^{\mathrm{b}}$, Ítalo Braga Castro ${ }^{\mathrm{a}, *}$ \\ a Departamento de Ciências do Mar, Universidade Federal de São Paulo (UNIFESP), Santos, SP, Brazil \\ ${ }^{\mathrm{b}}$ Departamento de Oceanografia, Universidade Federal de Pernambuco (UFPE), Recife, PE, Brazil \\ ${ }^{\mathrm{c}}$ Museu de Zoologia, Universidade de São Paulo (USP), São Paulo, SP, Brazil \\ d Departamento de Biologia, Universidade Católica de Pernambuco, Recife, PE, Brazil \\ e Instituto de Biociências, Universidade Estadual Paulista (UNESP), São Vicente, SP, Brazil
}

\section{A R T I C L E I N F O}

\section{Article history:}

Received 16 December 2016

Received in revised form

17 April 2017

Accepted 19 April 2017

Available online 22 April 2017

\section{Keywords:}

Shell alteration

Biomarker

Limpet

Proxy

Monitoring

Lottia subrugosa

\begin{abstract}
A B S T R A C T
During the last years, shell alterations in gastropods have been proposed as tools to be used in monitoring programs. However, no studies were so far performed investigating the relationships among shell parameters and classical biomarkers of damage. The relationship between shell alterations (biometrics, shape and elemental composition) and biomarkers (LPO and DNA strand break) was evaluated in the limpet $L$. subrugosa sampled along a contamination gradient in a multi-impacted coastal zone from southeastern Brazil. Statistically significant differences were detected among sites under different pollution levels. The occurrence of shell malformations was consistent with environmental levels of several hazardous substances reported for the studied area and related to lipid peroxidation and DNA damage. In addition, considering the low mobility, wide geographic distribution, ease of collection and abundance of limpets in coastal zones, this putative tool may be a cost-effective alternative to traditional biomarkers. Thus, shell alterations in limpets seem to be good proxies for assessing biological adverse effects in multi-impacted coastal zones.
\end{abstract}

() 2017 Elsevier Ltd. All rights reserved.

\section{Introduction}

Molluscs are widely used as model in studies of environmental contamination and toxicology due to their ecological and economic relevance (Laitano et al., 2013). Several gastropod and bivalve species have been proposed and used as tools in monitoring of environmental quality (Sericano et al., 1995) and ecotoxicology (Rittschof and Clellan-Green, 2005). Their wide geographic distribution, abundance, sedentary behaviour, ease of sampling and capacity to accumulate contaminants make molluscs suitable organisms for monitoring pollution (Oberdorster and ClellanGreen, 2003). In addition, several mollusc species are sensitive to anthropogenic impacts, exhibiting morphological (Nuñez et al.,

\footnotetext{
This paper has been recommended for acceptance by Dr. Harmon Sarah Michele.

* Corresponding author.

E-mail address: italobraga@gmail.com (Í.B. Castro).
}

2012), reproductive (Castro et al., 2012), biochemical (Márquez et al., 2011) and/or behavioural (Phelps et al., 1983) alterations when exposed to xenobiotics.

The structure of mollusc's shells preserves information about their life histories and environmental pressure related to morphology and chemical composition (Nuñez et al., 2012). Environmental parameters such as hydrodynamics (e.g., wave action), temperature, sun exposure (e.g., desiccation), type of substrate and salinity can lead to inter- and intraspecific changes in the shape, thickness, composition and sculpture of mollusc shells (Underwood, 1979; Vermeij, 1973). Studies using gastropods (Avaca et al., 2013; Laitano et al., 2013; Márquez et al., 2011; Nuñez et al., 2012) and bivalves (Alzieu, 2000; Alzieu et al., 1986) have shown that morphological and chemical composition changes in shells can also be induced by the exposure to hazardous chemicals in laboratory assays and along pollution gradients in the environment.

Limpets are patelliform gastropods numerically dominant in the macrobenthos of many intertidal rocky shore communities 
worldwide (Niu et al., 1992). Lottia subrugosa is a limpet species, presenting low mobility and broad geographic distribution along South American coastal zones (Rosenberg, 2016). In addition, it is easily identified and caught in rock shore substrates where it is usually abundant even on highly polluted sites. L. subrugosa presents a conical shell from which several biometric parameters can be readily assessed using biometric and morphometric analysis. These features favour the use of patelliform gastropods as suitable tools for evaluating environmental contamination. For instance, Nuñez et al. (2012) successfully identified distinct pollution levels in Argentina based on shell malformation of the limpet Siphonaria lessoni.

To the best of our knowledge, no studies were so far performed investigating the relationships among shell shape parameters, elemental composition and classical biomarkers used in marine pollution monitoring, such as lipid peroxidation (LPO) and DNA damage. These biomarkers are not specific to a particular group of contaminants, exhibiting a common response for either environmental parameters or multiple xenobiotics (Mayer et al., 1992). LPO and DNA damage have been extensively used as early proxies for deleterious effects produced by exposure to hazardous substances in marine species (Franzellitti et al., 2015; Pavlaki et al., 2016; Wen and Pan, 2016), including gastropods (Bhagat et al., 2016).

The use of limpet biometric parameters for monitoring marine chemical contamination might serve as a simple, cost-effective alternative for time-consuming, expensive methods currently available. Simultaneous assessment of traditional biomarkers and shell alterations in patelliform gastropods should be employed for validating biometrics as a tool for coastal biomonitoring. This study evaluated the relationship between shell alterations (biometrics, shape and elemental composition) and damage biomarkers (LPO and DNA strand break) in L. subrugosa sampled along a contamination gradient in a multi-impacted coastal zone from southeastern Brazil.

\section{Material and methods}

\subsection{Study area and sampling}

Santos is the major city of Baixada Santista metropolitan area (southeastern Brazil) with an urban population density of 1497 inhabitants per square kilometre. It hosts the largest industrial complex along the coast of Brazil and a major commercial port in Latin America (Fig. 1). Wastewaters from urban, port and industrial activities are released in Santos Estuarine System (SES) that flows into Santos Bay (Harari and Camargo, 1998). Several studies pointed out SES as a hot spot of hazardous chemicals, presenting estuary to bay gradient of trace metals (Kim et al., 2017), organic contaminants and toxicity (Abessa et al., 2005; Buruaem et al., 2013; Cesar et al., 2014; Torres et al., 2015).

At least 100 adult individuals $(9.0-15.5 \mathrm{~mm}$ ) of $L$. subrugosa were manually caught from rocky substrates during low tides at three sampling sites (P1, P2 and P3) located across a contamination gradient from estuary to bay (Fig. 1). Sites were chosen based on the occurrence of limpets as well as similarity of local hydrodynamics and salinity influence. Surface sediments (upper top $2 \mathrm{~cm}$ ) were collected next to each site using a stainless-steel Ekman grabber. In the laboratory, sediment samples were homogenized, frozen, freeze-dried and stored at $-20{ }^{\circ} \mathrm{C}$ until subsequent analysis. Organisms were identified and dissected for separation of soft tissues and shells.

\subsection{Chemical analyses in sediments}

Polycyclic aromatic hydrocarbons (PAHs), polychlorinated biphenyls (PCBs) and organochlorine pesticides (OCPs) in surface sediments were determined for confirming chemical contamination gradients across sampling sites (P1, P2 and P3). Extraction and clean up were carried out according to Burns et al. (1992). Briefly, $5 \mathrm{~g}$ of sediment was extracted in a Soxhlet apparatus with a mixture of $\mathrm{n}$-hexane and dichloromethane $(1: 1, \mathrm{v} / \mathrm{v})$. The extract was split into two fractions for column chromatography clean up. The first fraction was cleaned up with silica gel and alumina (both 5\% deactivated) for determination of PAHs. The second fraction was cleaned up with alumina ( $5 \%$ deactivated) for determination of PCBs and OCPs. Extracts were eluted with a mixture of $n$-hexane and dichloromethane $(7: 3, v / v)$. The purified extracts were injected into a gas chromatograph coupled to a mass spectrometer (GC-MS, Agilent Technologies, model 7820A/5975C).

Quality control criteria were based on limits typically used in marine pollution monitoring programs (e.g., Lauenstein and Cantillo, 1998; Wade and Cantillo, 1994). Limits of quantification (LQ) were $0.20,0.99$ and $0.99 \mathrm{ng} \mathrm{g}^{-1}$ dry weight ( $\mathrm{dw}$ ) for individual PAHs, PCBs and OCPs, respectively. Concentration of target analytes was calculated using internal standards (IS) whose recoveries were $83 \pm 17 \%$ (mean \pm standard deviation). Standard reference material (SRM 1944) from the National Institute of Standards and Technology (NIST), USA was extracted in duplicate for checking analytical accuracy and precision. Recovery of analytes in the SRM was $107 \pm 30 \%$ (mean \pm standard deviation) while the coefficient of variation (CV) between duplicates was $7 \pm 4 \%$ (mean \pm standard deviation).

\subsection{Lipid peroxidation and DNA damage analyses in tissues}

Soft tissues from 10 organisms randomly selected were immediately removed upon sampling. Thereafter, all samples were homogenized in buffer solution ( $\mathrm{NaCl} 100 \mathrm{mM}$, Hepes $\mathrm{NaOH} 25 \mathrm{mM}$, EDTA $0.1 \mathrm{mM}$, DTT $0.1 \mathrm{mM}, \mathrm{pH}$ 7.5) following procedures developed by Lafontaine et al. (2000). The homogenate was analysed for determination of DNA damage, lipid peroxidation (LPO) and total protein content. Total protein content of the homogenate was analysed according to the dye-binding principle (Bradford, 1976). DNA strand breaks was assessed by alkaline precipitation assay (Olive, 1988) based on the K-SDS precipitation of DNA-protein crosslink, followed by fluorometric detection of DNA strands (Gagné et al., 1995). DNA quantitation was achieved using Hoescht dye at a concentration of $100 \mathrm{nM}$ in $200 \mathrm{mM}$ TrisHCl, pH 8.5, containing $300 \mathrm{mM} \mathrm{NaCl}$ and $4 \mathrm{mM}$ sodium cholate. Salmon sperm DNA standards were used for calibration, and fluorescence readings were done at $360 \mathrm{~nm}$ (excitation) and $460 \mathrm{~nm}$ (emission). The results were expressed as $\mu$ g of DNA per milligram of total protein. LPO was measured according to Wills (1987), being determined in tissue homogenates by thiobarbituric acid. Thiobarbituric acid reactants (TBARS) were determined by fluorescence at $530 \mathrm{~nm}$ for excitation and $630 \mathrm{~nm}$ for emission using a fluorescence microplate reader. The results were expressed as $\mu \mathrm{g}$ of TBARS per milligram of total protein.

\subsection{Biometric and morphometric analyses in shells}

After complete drying in an oven $\left(60^{\circ} \mathrm{C}\right), 100$ shells from each sampling site were randomly selected and weighed on analytical balance $(0.01 \pm 0.003 \mathrm{mg})$. Biometric parameters (length, width, height) were measured using a digital calliper $(0.01 \pm 0.005 \mathrm{~mm})$ and thickness of shell apex was obtained using a digital micrometer $(0.001 \pm 0.0005 \mathrm{~mm})$. Measurements of shell specific gravity (relative density) were made by pycnometry according to DiResta et al. (1991).

Geometric morphometric analysis was performed using the 


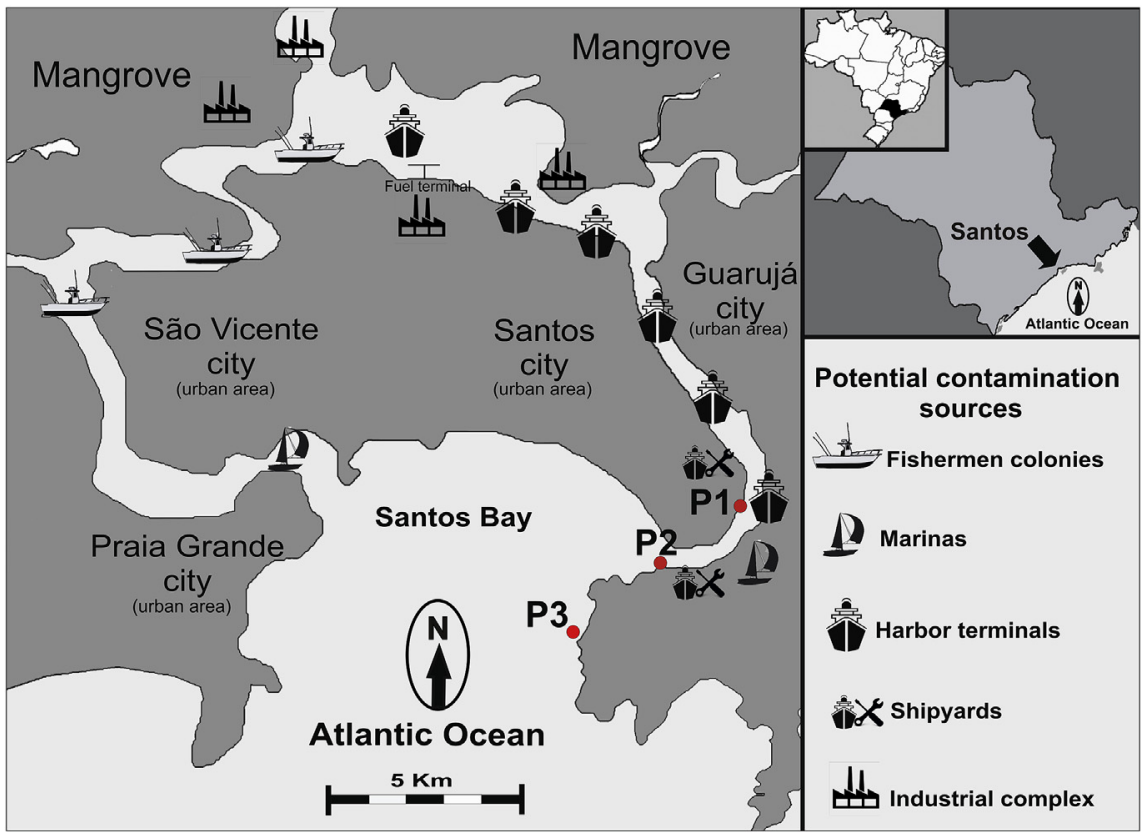

Fig. 1. Geographical setting and location of sampling sites (P1-P3) across a contamination gradient from Santos Estuary to Santos Bay, southeastern Brazil.

same 100 shells from each site (a total of 300 shells). They were placed in the same position and photographed from the right side using a Canon T3i D100 digital camera, $100 \mathrm{~mm}$ macro lens. Outlines of all specimens were digitalized using the software TPS dig2 (Rohlf, 1996). The shape of patelliform gastropods is convex and similar an irregular cone. However, shell variations were measured by outline analyses based on the Elliptic Fourier Shape Analysis (EFA-PCA) over the outline coordinates, using the algorithm described by Ferson et al. (1985). All Elliptic Fourier coefficients were mathematically normalized avoiding bias in the results (Rohlf and Archie, 1984).

\subsection{Elemental analyses in shells}

Levels of $\mathrm{Ca}, \mathrm{Na}, \mathrm{P}, \mathrm{S}, \mathrm{Cl}, \mathrm{Cr}, \mathrm{Mn}, \mathrm{Fe}, \mathrm{Ni}, \mathrm{Cu}, \mathrm{Zn}, \mathrm{Sr}, \mathrm{Cd}$ and $\mathrm{Pb}$ were determined from a pool of 10 shells randomly chosen from each sampling site according to ISO/TS 18507 (2015). In brief, shells were ground in mortar, sieved through a $63 \mu \mathrm{m}$ mesh and $50 \mathrm{mg}$ of shell powder were precisely weighed in glass tubes. Subsequently, $2.5 \mathrm{~mL}$ of non-ionic detergent (Triton $\left.{ }^{\circledR} \mathrm{X}-100\right)$ and $10 \mu \mathrm{L}$ of Ga solution $\left(1 \mathrm{~g} \mathrm{~L}^{-1}\right)$ - an IS - were added to the tubes and mixed during five minutes. For each measurement, $10 \mu \mathrm{L}$ of solution was spread over quartz support and oven dried $\left(60^{\circ} \mathrm{C}\right)$ for making a thin film. Measurements were carried out using a TXRF spectrometer (S2 Picofox - Bruker AXS Microanalysis GmbH, Berlin, Germany) for sequential readings using a live time of $1000 \mathrm{~s}$ (Towett et al., 2013). X-ray data were acquired and processed by XRF Software Spectra7 provided with the instrument. Quality control was based on IS recovery and CRM analyses. All samples were analyzed in triplicate.

\subsection{Statistical analyses}

Data sets normality and homogeneity of variances (biometric parameters, biomarker responses and shell elemental composition) were checked using Shapiro-Wilk and Levene's tests, respectively. Statistical relationships between shell length (SL) and apex thickness, height, weight and specific gravity were assessed by linear regression analysis. After, these biometric parameters were standardized by SL. Chemical contamination in sediment samples, biomarker responses, shell alterations and elemental composition were compared between sampling sites (P1, P2 and P3) using a Kruskal-Wallis test followed by Dunns post hoc test. Spearman rank order correlation analysis was used for investigating correlations between shell standardized alterations (biometric parameters) and biomarker responses (LPO and DNA damage). Statistical analyses described above were performed using Statistica ${ }^{\circledR}$ (version 12.0, Statsoft). A Mantel correlation analysis was used for assessing correlation among all biometric and biomarkers parameters. For geometric morphometric data, a principal component analyses (PCA) on the variance-covariance matrix (bootstrap, $n=10,000$ ) of the normalized Elliptic Fourier coefficients was performed using P.A.S.T. v.3.14 (Hammer et al., 2001). The multivariate regression was tested using a MANOVA to assess differences between the L. subrugosa shapes from the three sampling sites. All statistical analysis used 0.05 as critical level of significance.

\section{Results and discussion}

\subsection{Chemical contamination of surface sediments}

Levels of PAHs, PCBs and OCPs in surface sediments pointed out P1 (Balsa) as the most contaminated site, followed by P2 (Góes) and P3 (Ilha das Palmas) (Fig. 2). Total PAHs presented the highest concentrations, ranging from $27 \mathrm{ng} \mathrm{g}^{-1} \mathrm{dw}$ (P3) to $2667 \mathrm{ng} \mathrm{g}^{-1} \mathrm{dw}$ (P1). According to Baumard et al. (1998), the sites P1 and P2 can be classified as highly polluted, whereas P3 is slightly contaminated. In addition, ratios of both fluoranthene to fluoranthene plus pyrene $(\mathrm{Fl} / \mathrm{Fl}+\mathrm{Py})$ and indene[1,2,3-cd]pyrene to indene[1,2,3-cd]pyrene plus benzo[ghi]perylene (IP/IP + BghiP) (Yunker et al., 2002) were higher than 0.5 , indicating sources of pyrolytic PAHs in all sites. In fact, harbour areas are known to be hot spots of combustion PAHs (Laitano et al., 2015). Total PCBs detected in surface sediments from P1, P2 and P3 were 11.8, 12.4 and $1.13 \mathrm{ng} \mathrm{g}^{-1} \mathrm{dw}$, respectively. Profile of PCB congeners showed a prevalence of penta- and hexachlorinated biphenyls which is consistent with historical PCB mixtures used in the area (Bícego et al., 2006; Magalhães et al., 

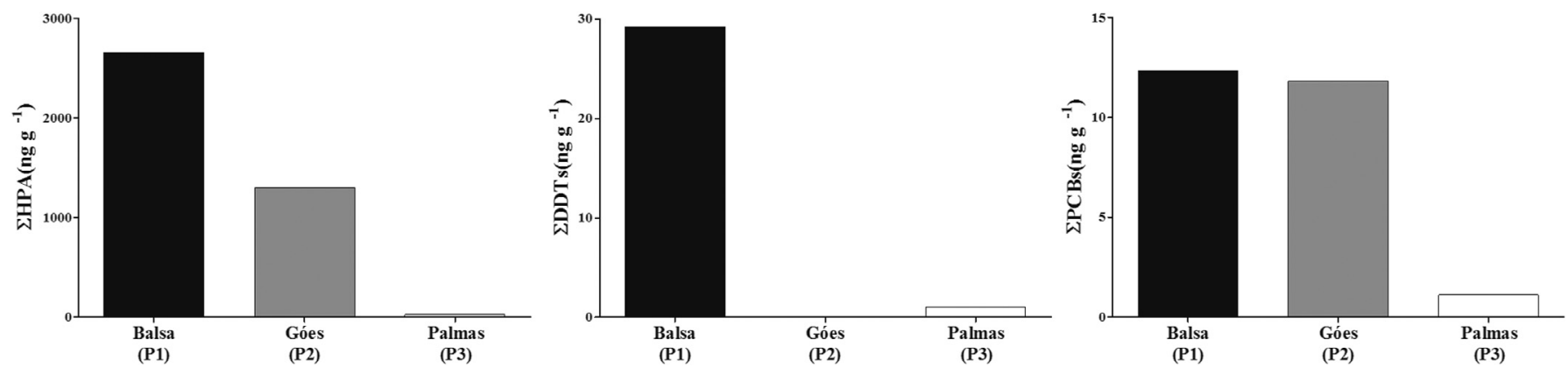

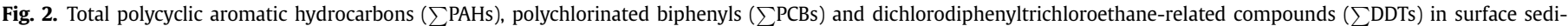
ments from Santos Estuary. Concentrations are expressed in $\mathrm{ng} \mathrm{g}^{-1}$ dry weight.

2012). These compounds have been widely studied due to their toxic effects and global mobility. PCBs comprise one of the most detected groups of persistent organic pollutants in surface sediments of multi-impacted coastal zones (Commendatore et al., 2015), including harbor areas (Rajendran et al., 2005). Regarding organochlorine pesticides, only DDT and its derivatives were detected in sediments from P1 and P3 (Fig. 2). As observed for $\sum$ PAHs and $\sum$ PCB, the highest $\sum$ DDTs levels were detected at P1 (29.2 $\mathrm{ng} \mathrm{g}^{-1} \mathrm{dw}$ ) followed by low concentration at P3 (1.1 $\mathrm{ng} \mathrm{g}^{-1}$ $\mathrm{dw})$. There are no major agricultural areas near Santos city, suggesting that DDT residues may be associated with public health campaigns or pesticide manufacturing plants.

As pointed out by previous studies (Buruaem et al., 2013; Maciel et al., 2016, 2015; Torres et al., 2015), the overall chemical contamination gradient in surface sediments decreased from estuarine-to marine-influenced sites. A recent investigation on trace metals ( $\mathrm{As}, \mathrm{Cr}, \mathrm{Cu}, \mathrm{Ni}, \mathrm{Pb}$ and $\mathrm{Zn}$ ) in the study area also revealed similar decreasing trends (Kim et al., 2017). Consequently, it is reasonable to assume that other hydrophobic hazardous chemicals such as antifouling biocides present the same spatial trends across the sampling sites (Artifon et al., 2016; Castro and Fillmann, 2012; Del Brio et al., 2016). Similar decreasing patterns have been reported for other industrialized harbor areas around the world (Barakat et al., 2002; Wang et al., 2016). Therefore, strong chemical evidences support the selected sites as suitable for evaluating limpet biological effects in field conditions.

\subsection{Lipid peroxidation and DNA damage}

Xenobiotics, their metabolites and reactive oxygen species (ROS) may promote several damages in biological organelles and molecules. Lipid peroxidation is a consequence of reactions with free radicals which lead to destruction of membrane lipids (Oliveira et al., 2009). On the other hand, single and double DNA strand breaks are often induced by exposure to hazardous agents. These biological alterations result from interaction with oxygen radicals or are due apoptosis/necrosis processes (Viarengo et al., 2007).

DNA damages in L. subrugosa decreased across the contamination gradient as follows: $15.8 \pm 4.1$ (mean \pm standard deviation), $12.3 \pm 3.3$ and $9.8 \pm 1.6 \mu \mathrm{g}$ DNA $\mathrm{mg}^{-1}$ protein in sites P1, P2 and P3, respectively (Fig. 3). Significant differences were observed only for P1 (Kruskal-Wallis followed by Dunn's test, $\mathrm{p}=0.0007$ ) which corresponds to site under higher contamination levels. Likewise, Spearman non-parametric tests indicated significant $(\mathrm{p}<0.05)$ and positive relationship between DNA damage and levels of PAH and PCBs $(r=0.68)$ measured in surface sediment samples from each site. On the other hand, no significant correlation (Spearman, $\mathrm{p}>0.05$ and $\mathrm{r}=0.33$ ) was observed with OCP concentrations. LPO showed the same pattern with higher signs of oxidative damages at
P1 (20,793 $\mu \mathrm{g}$ TBARS $\mathrm{mg}^{-1}$ protein), followed by P2 (8459 $\mu \mathrm{g}$ TBARS $\mathrm{mg}^{-1}$ protein) and P3 (4068 $\mu \mathrm{g}$ TBARS $\mathrm{mg}^{-1}$ ) (Fig. 3). As observed for DNA damage, LPO were significantly different only in P1 (Kruskal-Wallis followed by Dunn's test, $\mathrm{p}=0.01$ ) and related to PAH and PCB contamination in sediments (Spearman, $\mathrm{p}<0.05$ and $r=0.52$ ). Occurrence of LPO and DNA strand breaks suggest that ROS promoted damage on both membrane lipids and DNA. Such damages can be linked with several aspects of pathology and toxicity (Danellakis et al., 2011; Toufexi et al., 2013).

These findings are in agreement with results obtained by Buruaem et al. (2013) during an integrated quality assessment performed in the same area. The authors also found different levels of environmental degradation between P1 and P3. Positive correlations between biomarkers and contaminants such as PAHs and PCBs do not guarantee that these chemicals are the only responsible for the detected biochemical responses since Santos Estuary is a multi-impacted coastal area (Cesar et al., 2014).

Biomarker responses can be induced by several xenobiotics (individually or pooled) presenting different degrees of specificity related to biotic (age, sex, size) and abiotic (salinity, hypoxia, local hydrodynamics) variables (Raphael et al., 2016). Thus, bias may arise from differences among these parameters. Sites sampled in this study are located within an area not subject to significant salinity variations throughout the year (Gimiliani et al., 2016). They were also subject to similar hydrodynamics in order to minimize misinterpretations due to abiotic factors. In addition, organisms used to assess biomarker responses were of similar sizes (11-15 mm).

\subsection{Biometrics and morphometrics}

A total of 300 adult specimens of $L$. subrugosa were collected in the three sampling sites. Shells specific gravity (SSG) ranged from $2.52 \pm 0.24 \mathrm{~g} \mathrm{~cm}^{-3}$ (P3) to $2.74 \pm 0.44 \mathrm{~g} \mathrm{~cm}^{-3}$ (P1) while shell weight (SW) varied between $0.08 \pm 0.02 \mathrm{~g}(\mathrm{P} 1)$ and $0.13 \pm 0.01 \mathrm{~g}$ (P3) (Table 1). Shell height (SH), thickness (ST) and length (SL) also increased from P1 to P3. Shell lengths significantly differed among sampling sites (Kruskal-Wallis, $\mathrm{p}<0.0001$ ) and positively related to SSG $(p<0.0001$ and $r=0.11)$, SW $(p<0.0001$ and $r=0.31)$, SH $(p<0.0001$ and $r=0.57)$ and ST $(<0.0001$ and $r=0.22)$. Assessment of environmental impacts using biometric parameters may be biased by differences in organism sizes (Castro and Fillmann, 2012). In addition, a statistically significant relationship between SL and other biometric measurements were detected by linear regression analysis. Thus, before proceeding with further analyses SSG, SW, SH and ST data were normalized based on shell length. This approach has been routinely used in recent monitoring studies based on biometric measurements (Grimón et al., 2016; Paz-Villarraga et al., 2015; Petracco et al., 2015). 

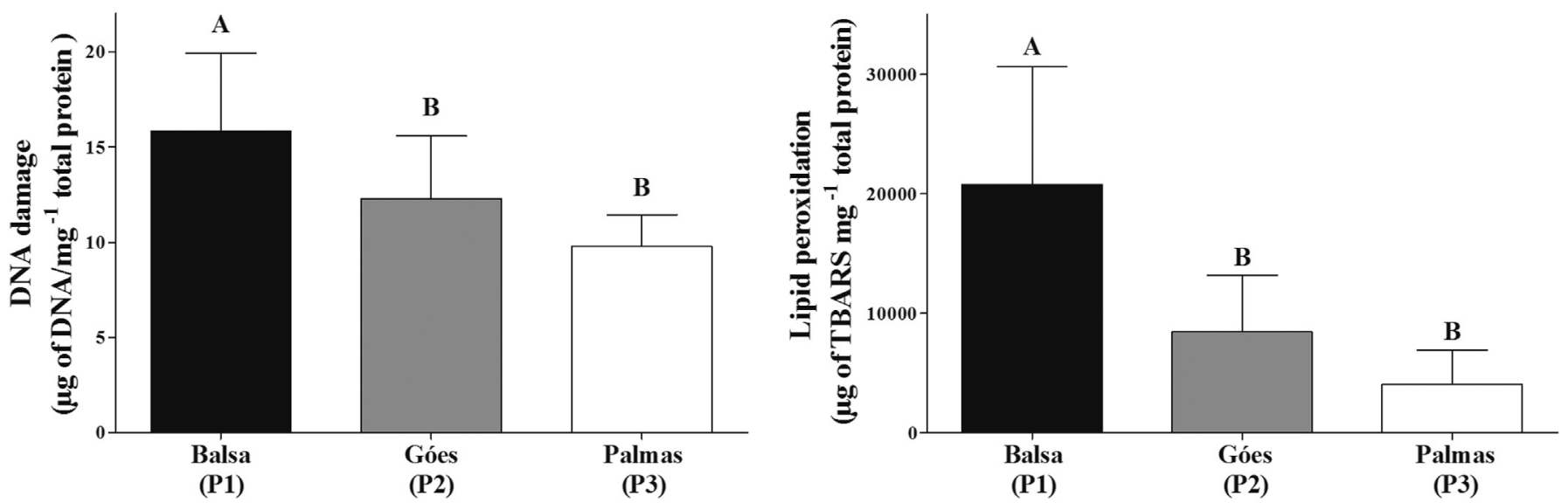

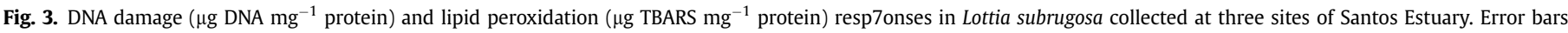
represent standard deviation. Distinct capital letters above columns denote statistical difference between sampling sites.

Table 1

Mean and standard deviation of shell biometric parameters of Lottia subrugosa collected at three sites of Santos Estuary.

\begin{tabular}{llll}
\hline Biometric Parameter & BALSA (P1) & GÓES (P2) & PALMAS (P3) \\
\hline Specific Gravity $\left(\mathrm{g} \mathrm{Cm}^{-3}\right)$ & $2.74 \pm 0.44$ & $2.65 \pm 0.20$ & $2.52 \pm 0.24$ \\
Weight $(\mathrm{g})$ & $0.08 \pm 0.02$ & $0.09 \pm 0.02$ & $0.13 \pm 0.01$ \\
Height $(\mathrm{mm})$ & $2.61 \pm 0.45$ & $3.29 \pm 0.47$ & $3.86 \pm 0.66$ \\
Thickness $(\mathrm{mm})$ & $0.21 \pm 0.09$ & $0.28 \pm 0.09$ & $0.42 \pm 0.15$ \\
Length $(\mathrm{mm})$ & $11.33 \pm 1.47$ & $12.16 \pm 0.83$ & $12.91 \pm 0.92$ \\
\hline
\end{tabular}

Specific gravity of L. subrugosa shells decreased significantly (Kruskal-Wallis, $\mathrm{p}<0.0001$ ) from the most to less contaminated sites (P1 to P3) differing among them (Dunn's post hoc test, $p<0.0001$ ) (Fig. 4). On the other hand, shell weight, height and thickness were statistically higher (Dunn's post hoc test, $\mathrm{p}<0.0001)$ at P3 where chemical contamination is lower. Accordingly, SSG, SW and SH (Fig. 4) showed a superior performance to differentiate among sites under different contamination levels than traditional biomarkers (see, Fig. 3). A Mantel correlation analysis performed using biomarker responses (DNA damage and LPO), contaminant levels ( $\sum$ PAHs, $\sum$ PCB and $\sum D D T s$ ) and sizenormalized biometric parameters indicated a significative $(p<0.001)$ and strong correlation (Mantel $r=0.81)$. Biomarkers are measurable variations in biochemical, physiological, histological or structural parameters as a consequence of exposure to hazardous substances (Forbes et al., 2006). Thus, these biometric measurements, easily obtained from $L$. subrugosa shells may be putative biomarkers of coastal contamination. Nuñez et al. (2012) inferred pollution effects based on morphological shell changes and soft tissues weight in the limpet Siphonaria lessoni from Mar del Plata (Argentina).

A Centroid multivariate linear regression showed a small negative allometric effect (Slope $=-0.000357, r^{2}=0.07761$; $\mathrm{p}<0.0001$ ). This effect was adequately removed by data normalization accomplished in PAST software. Morphometric analyses in L. subrugosa detected significant differences in shell size among P1, P2 and P3 (Fig. 5A). A principal component analysis (EFA-PCA) indicated that reductions in shell height (Fig. 5A and $\mathrm{B}, \mathrm{PC}-$ $01=80.02 \%$ of the variance) are related to more contaminated sites (P1), while higher shells were common in sites under moderate (P2) to low (P3) contamination rates. Additionally, PC - 02 corresponding to changes in shell length explained $4,19 \%$ of the observed variance. MANOVA detected significant differences between the L. subrugosa shapes from the three sampling sites (Wilk's lambda $=0.4402 ; \mathrm{F}=37.2 ; \mathrm{p}<0.0001$; Pillai's Trace $=0.5658$; $\mathrm{F}=2$ 29.09; $\mathrm{p}<0.0001$ ). Nuñez et al. (2012) also identified shell height and size as principal components for Siphonaria lessoni collected across a pollution gradient in Argentina. Several descriptors have been used as proxies for assessing environmental quality in coastal areas worldwide (Rosado et al., 2015). The use of morphometric geometric parameters for investigating variations in gastropod shell shape exposed to different levels of contamination has been recently demonstrated (Márquez et al., 2011; Primost et al., 2016). This technique allows comparison of several descriptors related to shape and size of organisms and/or structures (Rohlf and Marcus, 1993), being a valuable tool for assessing health of organisms exposed to environmental pollutants. In addition, geometric morphometrics was used for comparing shells collected over time, that is, before and after pollution events (Márquez et al., 2017). Márquez et al. (2017) validated marine gastropod shell shape as a proxy for marine pollution. However, our results showed that biometric and morphometric techniques generated similar interpretations for L. subrugosa (a patelliform gastropod with an easily measurable conical shell) suggesting that both approaches can be used in further studies.

Shell alterations in gastropods can be also induced by environmental and biological factors, such as wave action, salinity and predatory pressures (Crothers, 1983). Therefore, in the present study, the sampling strategy was established to minimize bias related these parameters. The samples were simultaneously obtained along a gradient with less than $5 \mathrm{~km}$ of extension and without spatial salinity variations (Gimiliani et al., 2016). In addition, the organisms were caught in rocky shores with similar patterns of lithology, wave exposure and community structure (including predatory pressures). Thus, the shell alterations detected in the present study are probably related to contamination gradient. However, experimental studies under laboratory conditions should be performed to confirm these findings, as already pointed out by Nuñez et al. (2012).

Studies investigating pollution effects recorded in mollusc shell have often related alterations to tributyltin (TBT) contamination (Laitano et al., 2013; Márquez et al., 2017, 2011; Nuñez et al., 2012; Primost et al., 2016). This antifouling biocide is considered one of the most man-made toxic substances and the most potent androgenic chemical ever introduced in significant amounts into marine environments (Almeida et al., 2007). TBT induces specific and nonspecific deleterious effects on marine biota, including malformation in oyster shells (Alzieu, 2000), hormonal imbalance in dolphins (Tanabe, 1999) and imposex in marine gastropods (Batista et al., 

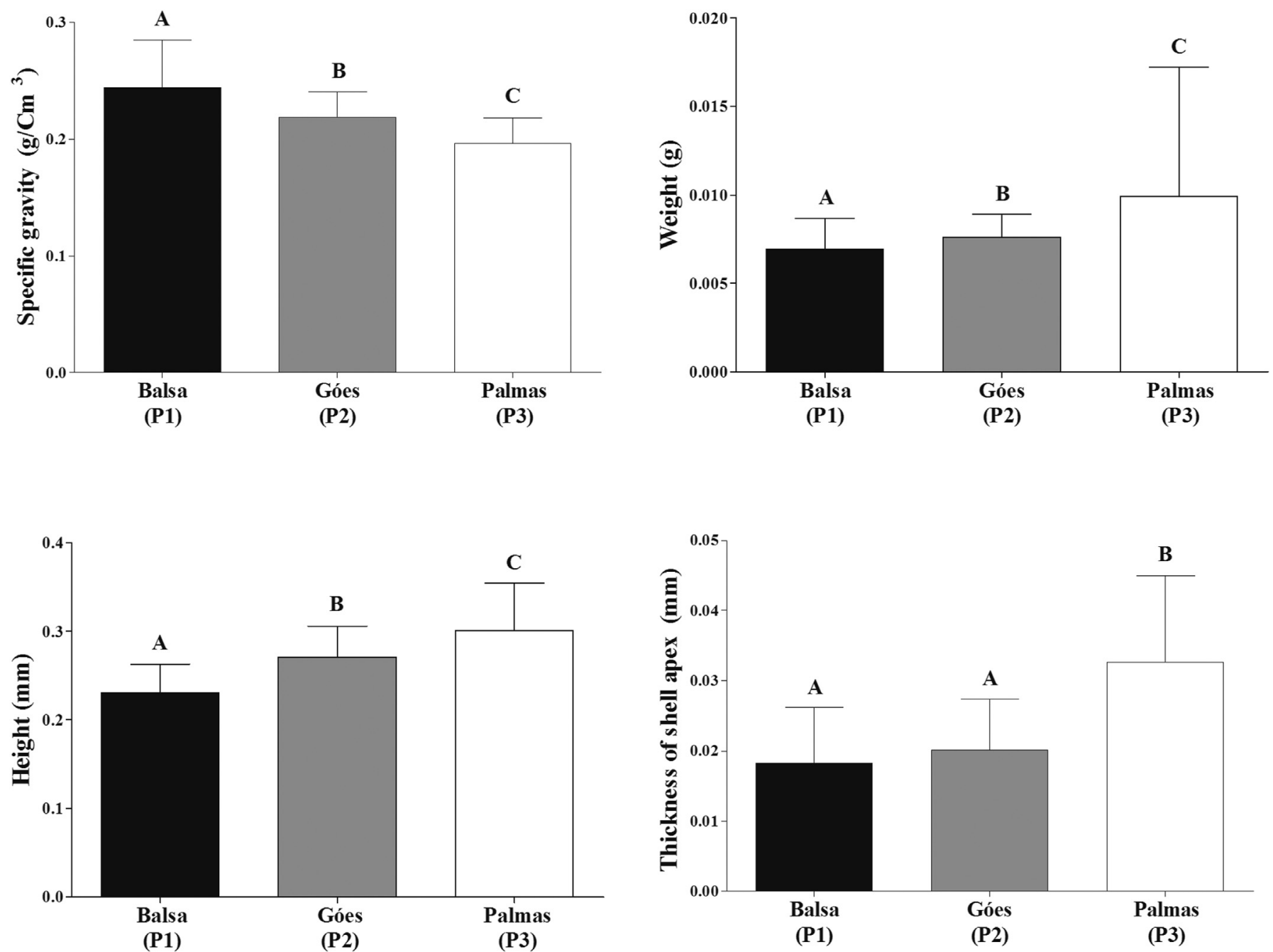

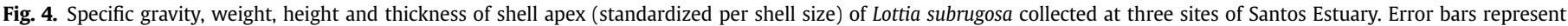
standard deviation. Distinct capital letters above columns denote statistical difference between sampling sites.

2016). In these cases, environmental impacts were directly associated with coastal areas under the influence of intense maritime activities such as ports, marinas and shipyards (Castro et al., 2012; Rossato et al., 2016). However, areas of intense ship traffic are usually multi-impacted coastal zones that receive inputs from several harmful substances, producing biological effects either individually or pooled (Moreira et al., 2017). Such a fact was evidenced in this study through detection of different pollutants along with simultaneous induction of DNA damage and lipid peroxidation. Furthermore, shell alterations in embryos of the gastropod Littorina saxatilis were related to the Prestige oil spill (Piñeira et al., 2008). Thus, specific contaminants and pathways causing alteration in shells of $L$. subrugosa remain unknown and should be addressed in future studies.

\subsection{Elemental analysis in shells}

Concentrations of $\mathrm{Ca}, \mathrm{Na}, \mathrm{P}$ and $\mathrm{S}$ in L. subrugosa shells were lower in P1 (the most polluted) and increased towards P2 and P3, whereas $\mathrm{Cl}$ levels presented an opposite trend (Table 2). Mollusc shells are organ-mineral composites, where the dominant mineral $\left(\mathrm{CaCO}_{3}\right)$ and several minor and trace elements (e.g., $\mathrm{Na}, \mathrm{K}, \mathrm{Mg}, \mathrm{Fe}, \mathrm{Sr}$, $\mathrm{Cl}$ and $\mathrm{S}$ ) are incorporated. Some ionic forms of these elements are absorbed from the environment and extruded by epithelial cells to extrapallial space, reaching supersaturation conditions that allow incorporation into shells (Marin et al., 2012). Thus, exposure to harmful substances and toxic trace elements may lead to changes in bioavailability or metabolic pathways affecting shell composition and structure. Decreasing concentrations of $\mathrm{Ca}$ and $\mathrm{Na}$ as well as increasing levels of $\mathrm{Cl}$ have been reported in bivalves exposed to toxic metals in both experimental (Faubel et al., 2008) and field (Kanduč et al., 2011) conditions. Laitano et al. (2013) detected the same patterns for $\mathrm{Ca}, \mathrm{Na}$ and $\mathrm{Cl}$ in shells of the limpet Bostrycapulus odites collected across a pollution gradient. Lower concentrations of $\mathrm{Ca}$ and $\mathrm{Na}$ in shells seem to indicate cellular disturbances promoted by non-essential metals such as $\mathrm{Cd}$ and $\mathrm{Pb}$. It is likely that $\mathrm{Cd}$ enters cells via $\mathrm{Na}^{+} / \mathrm{Ca}^{2+}$ exchanger and $\mathrm{Ca}^{2+}$ channels, competing directly with Ca because of their similar ionic radii (Matsuo et al., 2005). Indeed, Ortega et al. (2014) studied mechanisms of $\mathrm{Cd}^{2+}$ absorption through crab gill cells and observed that $C d$ influx appears to occur through $\mathrm{Ca}^{2+}$ channels and gill cell plasma membrane $\mathrm{Cd}^{2+} / \mathrm{Ca}^{2+}$ $\left(\mathrm{Na}^{+}\right)$exchanger. So $\mathrm{Cd}^{2+}$ could affect intracellular $\mathrm{Ca}^{2+}$ homeostasis due to extreme sensitivity of the Ca ATPase and other internal $\mathrm{Ca}^{2+}$ transport systems. Ortega et al. (2016) also observed that crabs living in polluted environments had higher gill and hepatopancreatic $\mathrm{Cd}$ transport associated with higher LPO in both gills 

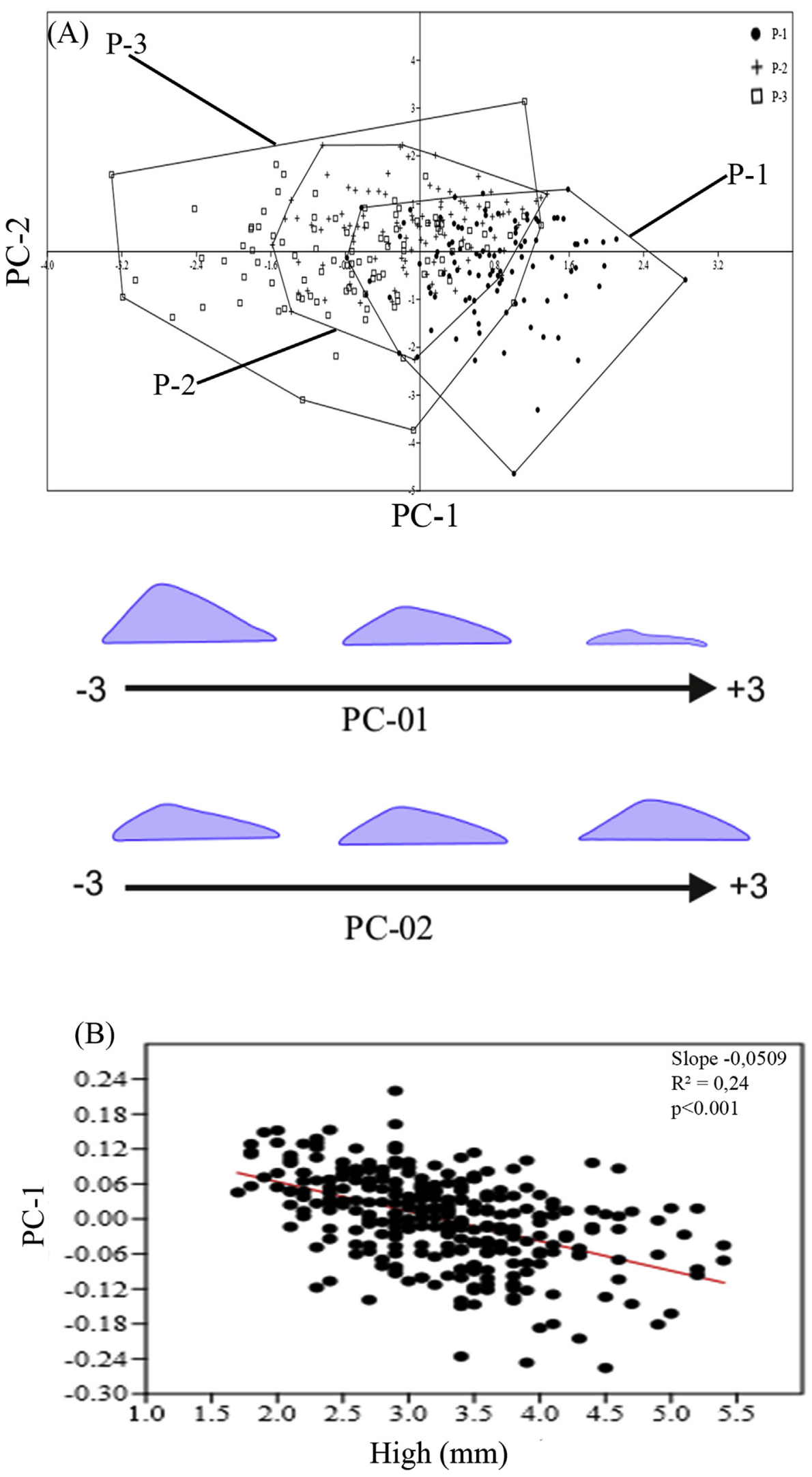

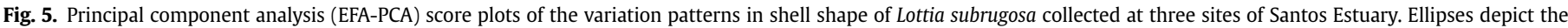

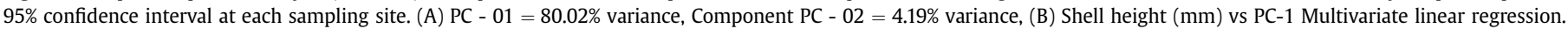


Table 2

Mean concentration and standard deviation $\left(\mu \mathrm{g} \mathrm{g}^{-1}\right)$ of selected elements in shell of Lottia subrugosa collected at three sites of Santos Estuary. Values in bold face denote statistically significant differences between sampling sites.

\begin{tabular}{llll}
\hline \multirow{2}{*}{ Elements } & Balsa $(\mathrm{P} 1)$ & Góes $(\mathrm{P} 2)$ & Palmas $(\mathrm{P} 3)$ \\
\cline { 2 - 4 } & Concentrations $\left(\mu \mathrm{g} \mathrm{g}^{-1}\right)$ & \\
\hline $\mathrm{Ca}$ & $311,360.1 \pm 8764.3$ & $324,080.3 \pm 7451.8$ & $\mathbf{3 8 0 , 4 6 5 . 7} \pm \mathbf{1 0 , 3 4 5 . 5}$ \\
$\mathrm{Na}$ & $14,753.5 \pm 863.5$ & $13,176.7 \pm 991.7$ & $\mathbf{3 0 , 6 0 4 . 6} \pm \mathbf{3 9 8 7 . 5}$ \\
$\mathrm{P}$ & $1363.6 \pm 126.7$ & $1328.7 \pm 98.4$ & $\mathbf{2 2 9 3 . 2} \pm \mathbf{1 1 2 . 4}$ \\
$\mathrm{S}$ & $\mathbf{4 5 3 . 0} \pm \mathbf{3 2 . 9}$ & $\mathbf{6 3 0 . 0} \pm \mathbf{5 3 . 2}$ & $\mathbf{1 0 3 7 . 0} \pm \mathbf{8 9 . 0}$ \\
$\mathrm{Cl}$ & $\mathbf{1 0 4 6 . 7} \pm \mathbf{1 0 0 . 3}$ & $485.0 \pm 62.6$ & $468.3 \pm 43.1$ \\
$\mathrm{Cr}$ & $30.7 \pm 15.3$ & $45.9 \pm 16.8$ & $\mathbf{2 3 . 0} \pm \mathbf{3 . 6}$ \\
$\mathrm{Mn}$ & $24.2 \pm 8.4$ & $21.2 \pm 6.4$ & $15.6 \pm 5.3$ \\
$\mathrm{Fe}$ & $\mathbf{5 1 3 . 3} \pm \mathbf{9 8 . 4}$ & $\mathbf{3 7 8 . 3} \pm \mathbf{7 7 . 3}$ & $\mathbf{2 2 3 . 0} \pm \mathbf{4 2 . 4}$ \\
$\mathrm{Ni}$ & $359.7 \pm 34.6$ & $386.0 \pm 20.3$ & $\mathbf{2 6 4 . 8} \pm \mathbf{1 8 . 4}$ \\
$\mathrm{Cu}$ & $\mathbf{3 . 8} \pm \mathbf{0 . 9}$ & $2.3 \pm 1.1$ & $2.7 \pm 0.7$ \\
$\mathrm{Zn}$ & $\mathbf{2 0 . 9} \pm \mathbf{2 . 2}$ & $\mathbf{6 . 4} \pm \mathbf{1 . 2}$ & $\mathbf{2 . 8} \pm \mathbf{0 . 7}$ \\
$\mathrm{Sr}$ & $2502.7 \pm 45.2$ & $2255.7 \pm 123.5$ & $2217.8 \pm 137.8$ \\
$\mathrm{Cd}$ & $\mathbf{7 2 2 . 3} \pm \mathbf{1 5 7 . 8}$ & $\mathbf{6 0 7 . 7} \pm \mathbf{1 0 8} .8$ & $\mathbf{2 7 4 . 0} \pm \mathbf{5 6 . 8}$ \\
$\mathrm{Pb}$ & $17.9 \pm 3.2$ & $15.3 \pm 3.6$ & $\mathbf{8 . 6} \pm \mathbf{1 . 9}$ \\
\hline
\end{tabular}

and hepatopancreas.

Overall, concentrations of $\mathrm{Cu}, \mathrm{Mn}, \mathrm{Fe}, \mathrm{Ni}, \mathrm{Zn}, \mathrm{Sr}, \mathrm{Cr}, \mathrm{Cd}$ and $\mathrm{Pb}$ in shells presented a downward trend from P1 (high contamination) to P3 (low contamination) (Table 2). According to the KruskalWallis test followed by Dunn's post hoc, statistically significant differences were observed between sampling sites for most elements, excepting Mn and Sr. Shell closing behaviour (minimizing exposure to contaminants), lysosome mobilization and partitioning to inert compartments (including shell) are known detoxification mechanisms used by molluscs exposed to metals (Nicholson and Szefer, 2003). P1 is located close to harbour terminals and shipyards that are local sources of metals, leading to their enrichment in the area (Buruaem et al., 2012). High levels of $\mathrm{Cu}, \mathrm{Mn}, \mathrm{Fe}, \mathrm{Ni}, \mathrm{Zn}, \mathrm{Sr}$, $\mathrm{Cr}, \mathrm{Cd}$ and $\mathrm{Pb}$ in $L$. subrugosa shells from $\mathrm{P} 1$ are probable reflecting metal availability related to local inputs. Cravo et al. (2004) observed similar pattern when studying Patella aspera collected from two sites exposed to distinct water quality conditions on the southern coast of Portugal. In gastropod shells, metal ions are incorporated into the aragonite crystal by replacing calcium ions (Babukutty and Chacko, 1992). Our results indicate that $\mathrm{Ca}$ and $\mathrm{Na}$ are being replaced by other metals in shells collected from highly contaminated sites. Although it was not possible to assess statistical relationships between shell elemental composition and specific gravity, our findings suggest that higher specific gravity in shells from P1 might be caused by metal substitution. However, additional and specific studies should be performed for confirming this hypothesis. Regarding lower concentrations of $\mathrm{P}$ and $\mathrm{S}$ in shells from P1, we hypothesized that it may be due to a reduction in shell organic matrix which is mostly composed of proteins. Further studies should be performed to confirm this hypothesis since organic constituents drastically influence shape and properties of shell biominerals (Marin et al., 2007).

\section{Conclusion}

Statistically significant alterations in shell specific gravity, biometry (height, apex thickness and weight), shape and elemental composition were found in the limpet Lottia subrugosa collected across a pollution gradient in the Santos Estuary. These changes were related to responses of biomarkers (DNA damage and lipid peroxidation) and chemical contamination. Shell malformations observed in the molluscs are consistent with environmental levels of several hazardous substances reported by other studies in the area. In addition, considering the low mobility, wide geographic distribution, ease of collection and abundance of limpets in coastal zones, this putative tool may be a lower-cost alternative to traditional biomarkers. Thus, shell alterations in limpets should be experimentally investigated to confirm its applicability as good proxies for assessing pollution of multi-impacted coastal environments.

\section{Acknowledgments}

This study was funded by Fundação de Amparo à Pesquisa do Estado de São Paulo (FAPESP/Proc. n ${ }^{\circ}$ 2015/25063-0). F.N. Begliomini was sponsored by PIBIC/CNPq. L.A. Maranho is funded by CNPq (166122/2015-7). I.B. Castro (PQ 306486/2015-6) and C.D.S. Pereira (PQ 307074/2013-7) are recipients of research productivity fellowships from the Brazilian Research Council (CNPq). The authors thank Fabio Cop and Felipe Gusmão for the support given in statistical analyses.

\section{References}

Abessa, D.M. de S., Zaroni, L.P., Sousa, E.C.P.M. de, Gasparro, M.R., Pereira, C.D.S. Rachid, B.R. de F., Depledge, M., King, R.S., 2005. Physiological and cellular responses in two populations of the mussel Perna perna collected at different sites from the coast of São Paulo, Brazil. Braz. Arch. Biol. Technol. 48, 217-225.

Almeida, E., Diamantino, T.C., de Sousa, O., 2007. Marine paints: the particular case of antifouling paints. Prog. Org. Coat. 59, 2-20.

Alzieu, C., 2000. Environmental impact of TBT: the French experience. Sci. Total Environ. 258, 99-102.

Alzieu, C.L., Sanjuan, J., Deltreil, J.P., Borel, M., 1986. Tin contamination in Arcachon Bay: effects on oyster shell anomalies. Mar. Pollut. Bull. 17, 494-498.

Artifon, V., Castro, I., Fillmann, G., 2016. Spatiotemporal appraisal of TBT contamination and Imposex along a tropical bay (Todos os Santos Bay, Brazil). Environ. Sci. Pollut. Res. 1-9.

Avaca, M.S., Narvarte, M., Martín, P., van der Molen, S., 2013. Shell shape variation in the nassariid buccinanops globulosus in Northern Patagonia. Helgol. Mar. Res. 67, 567-577. http://dx.doi.org/10.1007/s10152-013-0344-5.

Babukutty, Y., Chacko, J., 1992. Trace metals in an estuarine bivalve from the Southwest Coast of India. Ambio 292-296.

Barakat, A.O., Kim, M., Qian, Y., Wade, T.L., 2002. Organochlorine pesticides and PCB residues in sediments of alexandria harbour. Egypt. Mar. Pollut. Bull. 44 1426-1434. http://dx.doi.org/10.1016/S0025-326X(02)00313-2.

Batista, R.M., Castro, I.B., Fillmann, G., 2016. Imposex and butyltin contamination still evident in Chile after TBT global ban. Sci. Total Environ. 566-567, 446-453. http://dx.doi.org/10.1016/j.scitotenv.2016.05.039.

Baumard, P., Budzinski, H., Michon, Q., Garrigues, P., Burgeot, T., Bellocq, J., 1998. Origin and bioavailability of PAHs in the mediterranean sea from mussel and sediment records. Estuar. Coast. Shelf Sci. 47, 77-90. http://dx.doi.org/10.1006/ ecss.1998.0337.

Bhagat, J., Sarkar, A., Ingole, B.S., 2016. DNA damage and oxidative stress in marine gastropod morula granulata exposed to phenanthrene. Water. Air. Soil Pollut. 227, 1-12. http://dx.doi.org/10.1007/s11270-016-2815-1.

Bícego, M.C., Taniguchi, S., Yogui, G.T., Montone, R.C., Silva, D.A.M. da, Lourenço, R.A., Martins, C. de C., Sasaki, S.T., Pellizari, V.H., Weber, R.R., 2006. Assessment of contamination by polychlorinated biphenyls and aliphatic and aromatic hydrocarbons in sediments of the Santos and São Vicente estuary system, São Paulo, Brazil. Mar. Pollut. Bull. 52, 1804-1816. http://dx.doi.org/10.1016/ j.marpolbul.2006.09.011.

Bradford, M.M., 1976. A rapid and sensitive method for the quantitation of microgram quantities of protein utilizing the principle of protein-dye binding. Anal. Biochem. 72, 248-254.

Burns, K., Farrington, J., Ehrhardt, M., Palmork, K., 1992. Determination of Petroleum Hydrocarbons in Sediments. Ed 20: Reference methods for marine pollution studies. Unesco, Intergovernmental Oceanographic Commission, United Nations Environment Programme, 75 pp.

Buruaem, L.M., Castro, Í.B., Hortellani, M.A., Taniguchi, S., Fillmann, G., Sasaki, S.T., Varella Petti, M.A., Sarkis, J.E. de S., Bícego, M.C., Maranho, L.A., Davanso, M.B. Nonato, E.F., Cesar, A., Costa-Lotufo, L.V., Abessa, D.M. de S., 2013. Integrated quality assessment of sediments from harbour areas in Santos-São Vicente estuarine system, Southern Brazil. Estuar. Coast. Shelf Sci. 130, 179-189.

Buruaem, L.M., Hortellani, M.A., Sarkis, J.E., Costa-Lotufo, L.V., Abessa, D.M.S., 2012. Contamination of port zone sediments by metals from Large Marine ecosystems of Brazil. Mar. Pollut. Bull. 64, 479-488. http://dx.doi.org/10.1016/ j.marpolbul.2012.01.017.

Castro, Í.B., Fillmann, G., 2012. High tributyltin and imposex levels in the commercial muricid Thais chocolata from two peruvian harbor areas. Environ. Toxicol. Chem. 31, 955-960.

Castro, I.B., Rocha-Barreira, C.A., Fernandez, M.A., Bigatti, G., 2012. Transplant bioassay induces different imposex responses in two species of the genus Stramonita. Mar. Biol. Res. 8, 397-404. 
Cesar, A., Lia, L.R.B., Pereira, C.D.S., Santos, A.R., Cortez, F.S., Choueri, R.B., De Orte, M.R., Rachid, B.R.F., 2014. Environmental assessment of dredged sediment in the major Latin American seaport (Santos, São Paulo - Brazil): an integrated approach. Sci. Total Environ. 497-498, 679-687. http://dx.doi.org/10.1016/ j.scitotenv.2014.08.037.

Commendatore, M.G., Franco, M.A., Gomes Costa, P., Castro, I.B., Fillmann, G., Bigatti, G., Esteves, J.L., Nievas, M.L., 2015. Butyltins, polyaromatic hydrocarbons, organochlorine pesticides, and polychlorinated biphenyls in sediments and bivalve mollusks in a mid-latitude environment from the Patagonian coastal zone. Environ. Toxicol. Chem. 34, 2750-2763. http://dx.doi.org/10.1002/ etc.3134.

Cravo, A., Bebianno, M.J., Foster, P., 2004. Partitioning of trace metals between soft tissues and shells of Patella aspera. Environ. Int. 30, 87-98. http://dx.doi.org/ 10.1016/S0160-4120(03)00154-5.

Crothers, J.H., 1983. Variation in dog-whelk shells in relation to wave action and crab predation. Biol. J. Linn. Soc. 20, 85-102. http://dx.doi.org/10.1111/j.10958312.1983.tb01591.x.

Danellakis, D., Ntaikou, I., Kornaros, M., Dailianis, S., 2011. Olive oil mill wastewater toxicity in the marine environment: alterations of stress indices in tissues of mussel Mytilus galloprovincialis. Aquat. Toxicol. 101, 358-366. http:// dx.doi.org/10.1016/j.aquatox.2010.11.015.

Del Brio, F., Commendatore, M., Castro, Í., Costa, P., Fillmann, G., Bigatti, G., 2016. Distribution and bioaccumulation of butyltins in the edible gastropod odontocymbiola magellanica. Mar. Biol. Res. 12 http://dx.doi.org/10.1080/ 17451000.2016.1169296.

DiResta, G.R., Lee, J., Arbit, E., 1991. Measurement of brain tissue specific gravity using pycnometry gene. J. Neurosci. Methods 245-251.

Faubel, D., Lopes-Lima, M., Freitas, S., Pereira, L., Andrade, J., Checa, A., Frank, H., Matsuda, T., Machado, J., 2008. Effects of $\mathrm{Cd} 2+$ on the calcium metabolism and shell mineralization of bivalve Anodonta cygnea. Mar. Freshw. Behav. Physiol. 41, 131-146.

Ferson, S., Rohlf, J., Koehn, R.K., 1985. Measuring shape variation of two-dimensional outlines. Syst. Zool. 34, 59-68.

Forbes, V.E., Palmqvist, A., Bach, L., 2006. The use and misuse of biomarkers in ecotoxicology. Environ. Toxicol. Chem. 25, 272-280.

Franzellitti, S., Buratti, S., Du, B., Haddad, S.P., Chambliss, C.K., Brooks, B.W., Fabbri, E., 2015. A multibiomarker approach to explore interactive effects of propranolol and fluoxetine in marine mussels. Environ. Pollut. 205, 60-69. http://dx.doi.org/10.1016/j.envpol.2015.05.020.

Gagné, F., Trottier, S., Blaise, C., Sproull, J., Ernst, B., 1995. Genotoxicity of sediment extracts obtained in the vicinity of a creosote-treated wharf to rainbow trout hepatocytes. Toxicol. Lett. 78, 175-182.

Gimiliani, G.T., Fontes, R.F.C., Abessa, D.M. de S., 2016. Modeling the dispersion of endocrine disruptors in the Santos estuarine System (Sao Paulo state, Brazil). Braz. J. Oceanogr. 64, 1-8.

Grimón, R.O.R., Arroyo Osorio, M.F., de Freitas, D.M., Castro, Í.B., 2016. Tributyltin impacts in Galapagos Islands and Ecuadorian shore: marine protected areas under threat. Mar. Policy 69, 24-31. http://dx.doi.org/10.1016/ j.marpol.2016.03.017.

Hammer, Ø., Harper, D., Ryan, P., 2001. PAST: paleontological statistics software package for education and data analysis palaeontol. Electronica 4, 1-9.

Harari, J., Camargo, R. de, 1998. Modelagem numérica da região costeira de Santos (SP): circulação de maré. Rev. Bras. Oceanogr. 46, 135-156.

ISO/TS 18507, 2015. Surface Chemical Analysis - Use of Total Reflection X-ray Fluorescence Spectroscopy in Biological and Environmental Analysis.

Kanduč, T., Medaković, D., Hamer, B., 2011. Mytilus galloprovincialis as a bioindicator of environmental conditions: the case of the eastern coast of the Adriatic Sea. Isot. Environ. Health Stud. 47, 42-61.

Kim, B.S.M., Angeli, J.L.F., Ferreira, P.A. de L., Sartoretto, J.R., Miyoshi, C., de Mahiques, M.M., Figueira, R.C.L., 2017. Use of a chemometric tool to establish the regional background and assess trace metal enrichment at Baixada Santista - Ssoutheastern Brazil. Chemosphere 166, 372-379. http://dx.doi.org/10.1016/ j.chemosphere.2016.09.132.

Lafontaine, Y., Gagné, F., Blaise, C., Costan, G., Gagnon, P., Chan, H., 2000. Biomarkers in zebra mussels (Dreissena polymorpha) for the assessment and monitoring of water quality of the St Lawrence River (Canada). Aquat. Toxicol. 50, 51-71.

Laitano, M., Castro, Í., Costa, P., Fillmann, G., Cledón, M., 2015. Butyltin and PAH contamination of mar del plata port (Argentina) sediments and their influence on adjacent coastal regions. Bull. Environ. Contam. Toxicol. 1-8. http:// dx.doi.org/10.1007/s00128-015-1637-y.

Laitano, M.V., Nuñez, J.D., Cledón, M., 2013. Shell alterations in the limpet Bostrycapulus odites: a bioindicator of harbour pollution and mine residuals. Ecol. Indic. 34, 345-351. http://dx.doi.org/10.1016/j.ecolind.2013.05.022.

Lauenstein, G., Cantillo, A.Y., 1998. Sampling and Analytical Methods of the National Status and Trends Program Mussel Watch Project: 1993-1996 Update.

Maciel, D.C., de Souza, J.R.B., Taniguchi, S., Bícego, M.C., Schettini, C.A.F., ZanardiLamardo, E., 2016. Hydrocarbons in sediments along a tropical estuary-shelf transition area: sources and spatial distribution. Mar. Pollut. Bull. 113, 566-571. http://dx.doi.org/10.1016/j.marpolbul.2016.08.048.

Maciel, D.C., de Souza, J.R.B., Taniguchi, S., Bícego, M.C., Zanardi-Lamardo, E., 2015. Sources and distribution of polycyclic aromatic hydrocarbons in a an urbanized tropical estuary and adjacent shelf, Northeast of Brazil. Mar. Pollut. Bull. 101, 429-433. http://dx.doi.org/10.1016/j.marpolbul.2015.09.051.

Magalhães, C.A., Taniguchi, S., Cascaes, M.J., Montone, R.C., 2012. PCBs, PBDEs and organochlorine pesticides in crabs Hepatus pudibundus and Callinectes danae from Santos Bay, State of São Paulo, Brazil. Mar. Pollut. Bull. 64, 662-667. http:// dx.doi.org/10.1016/j.marpolbul.2011.12.020.

Marin, F., Le Roy, N., Marie, B., 2012. The formation and mineralization of mollusk shell. Front. Biosci. 4, 1099-1125.

Marin, F., Luquet, G., Marie, B., Medakovic, D., 2007. Molluscan shell proteins: primary structure, origin, and evolution. Curr. Top. Dev. Biol. 80, 209-276.

Márquez, F., González-José, R., Bigatti, G., 2011. Combined methods to detect pollution effects on shell shape and structure in Neogastropods. Ecol. Indic. 11 248-254. http://dx.doi.org/10.1016/j.ecolind.2010.05.001.

Márquez, F., Primost, M.A., Bigatti, G., 2017. Shell shape as a biomarker of marine pollution historic increase. Mar. Pollut. Bull. 114, 816-820. http://dx.doi.org/ 10.1016/j.marpolbul.2016.11.018.

Matsuo, A.Y.O., Wood, C.M., Val, A.L., 2005. Effects of copper and cadmium on ion transport and gill metal binding in the Amazonian teleost tambaqui (Colossoma macropomum) in extremely soft water. Aquat. Toxicol. 74, 351-364. http:// dx.doi.org/10.1016/j.aquatox.2005.06.008.

Mayer, F.L., Versteeg, D.J., McKee, M.J., Folmar, L.C., Graney, R.L., McCume, D.C. Rattner, B.A., 1992. Physiological and nonspecific biomarkers. In: Huggett, Robert J., Kimerle, Richard A., Mehrle Jr., Paul M., Bergman, Harold L (Eds.), Biomarkers: Biochemical, Physiological, and Histological Markers of Anthropogenic Stress. Lewis Publishers, Boca Raton, Florida, pp. 5-85.

Moreira, L.B., Castro, Í.B., Hortellani, M.A., Sasaki, S.T., Taniguchi, S., Petti, M.A.V., Fillmann, G., Sarkis, J.E.S., Bícego, M.C., Costa-Lotufo, L.V., Abessa, D.M.S., 2017. Effects of harbor activities on sediment quality in a semi-arid region in Brazil. Ecotoxicol. Environ. Saf. 135, 137-151. http://dx.doi.org/10.1016/ j.ecoenv.2016.09.020.

Nicholson, S., Szefer, P., 2003. Accumulation of metals in the soft tissues, byssus and shell of the mytilid mussel Perna viridis (Bivalvia: mytilidae) from polluted and uncontaminated locations in Hong Kong coastal waters. Mar. Pollut. Bull. 46 1040-1043.

Niu, C., Nakao, S., Goshima, S., 1992. Growth, population age structure and mortality of the limpet Collisella heroldi (DUNKER, 1861)(gastropoda: acmaeidae) in an intertidal rocky shore, in Southern Hokkaido. Bull. Jpn. Soc. Sci. Fish. 58, 1405-1410.

Nuñez, J.D., Laitano, M.V., Cledón, M., 2012. An intertidal limpet species as a bioindicator: pollution effects reflected by shell characteristics. Ecol. Indic. 14 178-183. http://dx.doi.org/10.1016/j.ecolind.2011.07.015.

Oberdorster, E., Clellan-Green, P., 2003. Expression of the peptide hormone APGWamide in imposex and normal snails: a neurotoxicity mechanism for imposex induction. Integr. Comp. Biol. 43, 896, 896.

Olive, P.L., 1988. DNA precipitation assay: a rapid and simple method for detecting DNA damage in mammalian cells. Environ. Mol. Mutagen 11, 487-495.

Oliveira, M., Maria, V.L., Ahmad, I., Serafim, A., Bebianno, M.J., Pacheco, M. Santos, M.A., 2009. Contamination assessment of a coastal lagoon (Ria de Aveiro, Portugal) using defence and damage biochemical indicators in gill of Liza aurata - an integrated biomarker approach. Environ. Pollut. 157, 959-967. http://dx.doi.org/10.1016/j.envpol.2008.10.019.

Ortega, P., Custódio, M.R., Zanotto, F.P., 2014. Characterization of cadmium plasma membrane transport in gills of a mangrove crab Ucides cordatus. Aquat. Toxicol. 157, 21-29. http://dx.doi.org/10.1016/j.aquatox.2014.09.006.

Ortega, P., Vitorino, H.A., Moreira, R.G., Pinheiro, M.A.A., Almeida, A.A Custódio, M.R., Zanotto, F.P., 2016. Physiological differences in the crab Ucides cordatus from two populations inhabiting mangroves with different levels of cadmium contamination. n/a-n/a Environ. Toxicol. Chem.. http://dx.doi.org/ 10.1002/etc.3537.

Pavlaki, M.D., Araújo, M.J., Cardoso, D.N., Silva, A.R.R., Cruz, A., Mendo, S. Soares, A.M.V.M., Calado, R., Loureiro, S., 2016. Ecotoxicity and genotoxicity of cadmium in different marine trophic levels. Environ. Pollut. 215, 203-212. http://dx.doi.org/10.1016/j.envpol.2016.05.010.

Paz-Villarraga, C.A., Castro, I.B., Miloslavich, P., Fillmann, G., 2015. Venezuelan caribbean sea under the threat of TBT. Chemosphere 119, 704-710.

Petracco, M., Camargo, R., Berenguel, T., de Arruda, N.L.P., del Matto, L., Amado, L., Corbisier, T., Castro, Í., Turra, A., 2015. Evaluation of the use of Olivella minuta (Gastropoda, Olividae) and Hastula cinerea (Gastropoda, Terebridae) as TBT sentinels for sandy coastal habitats. Environ. Monit. Assess. 187, 1-11. http:// dx.doi.org/10.1007/s10661-015-4650-z.

Phelps, H., Hardy, J., Pearson, W., Apts, C., 1983. Clam burrowing behaviour: inhibition by copper-enriched sediment. Mar. Pollut. Bull. 14, 452-455. http:// dx.doi.org/10.1016/0025-326X(83)90044-9.

Piñeira, J., Quesada, H., Rolán-Alvarez, E., Caballero, A., 2008. Genetic impact of the Prestige oil spill in wild populations of a poor dispersal marine snail from intertidal rocky shores. Mar. Pollut. Bull. 56, 270-281. http://dx.doi.org/10.1016/ j.marpolbul.2007.10.020.

Primost, M., Bigatti, G., Marquez, F., 2016. Shell shape as indicator of pollution in marine gastropods affected by imposex. Mar. Freshw. Res. 67 (12), 1948-1954. http://dx.doi.org/10.1071/MF15233.

Rajendran, R.B., Imagawa, T., Tao, H., Ramesh, R., 2005. Distribution of PCBs, HCHs and DDTs, and their ecotoxicological implications in Bay of Bengal, India. Environ. Int. 31, 503-512. http://dx.doi.org/10.1016/j.envint.2004.10.009.

Raphael, S., Aude, J., Olivier, P., Mélissa, P.-L., Aurélien, B., Christophe, B., Jean Marc, P., Sylvie, B., Alain, D., Wilfried, S., 2016. Characterization of a genotoxicity biomarker in three-spined stickleback (Gasterosteus aculeatusL.): biotic variability and integration in a battery of biomarkers for environmental monitoring. Environ. Toxicol. 31, 415-426. http://dx.doi.org/10.1002/tox.22055.

Rittschof, D., Clellan-Green, P., 2005. Molluscs as multidisciplinary models in 
environment toxicology. Mar. Pollut. Bull. 50, 369-373.

Rohlf, F.., 1996. Morphometric spaces, shape components and the effects of linear transformations. In: Marcus, L.F., Corti, M., Loy, A., Naylor, G.J.P., Slice, D.E. (Eds.) Advances in Morphometrics. Springer, US, Boston, MA, pp. 117-129.

Rohlf, F.J., Archie, W., 1984. A Comparison of Fourier methods for the description of wing shape in mosquitoes (Diptera: Culidae). Syst. Zool. 33, 302-317.

Rohlf, F.J., Marcus, L.F., 1993. A revolution morphometrics. Trends Ecol. Evol. 8, 129-132.

Rosado, D., Usero, J., Morillo, J., 2015. Application of a new integrated sediment quality assessment method to Huelva estuary and its littoral of influence (Southwestern Spain). Mar. Pollut. Bull. 98, 106-114. http://dx.doi.org/10.1016/ j.marpolbul.2015.07.008.

Rosenberg, G., 2016. Lottia subrugosa (d'Orbigny, 1846). In: MolluscaBase (2015) (Accessed through: World Register of Marine Species at).

Rossato, M., Castro, I.B., Paganini, C.L., Colares, E.P., Fillmann, G., Pinho, G.L.L., 2016 Sex steroid imbalances in the muricid Stramonita haemastoma from TBT contaminated sites. Environ. Sci. Pollut. Res. 23, 7861-7868. http://dx.doi.org 10.1007/s11356-015-5942-0.

Sericano, J.L., Wade, T.L., Jackson, T.J., Brooks, J.M., Tripp, B.W., Farrington, J.W. Mee, L.D., Readmann, J.W., Villeneuve, J.P., Goldberg, E.D., 1995. Trace organic contamination in the americas: an overview of the US national status and trends and the international mussel watch programmes. Mar. Pollut. Bull. 31 $214-225$.

Tanabe, S., 1999. Butyltin contamination in marine mammals - a review. Mar. Pollut. Bull. 39, 62-72.

Torres, R., Cesar, A., Pastor, V., Pereira, C.S., Choueri, R., Cortez, F., Morais, R. Abessa, D.S., do Nascimento, M.L., Morais, C., Fadini, P., Del Valls Casillas, T., Mozeto, A., 2015. A critical comparison of different approaches to sedimentquality assessments in the Santos estuarine system in Brazil. Arch. Environ. Contam. Toxicol. 68, 132-147. http://dx.doi.org/10.1007/s00244-014-0099-2.

Toufexi, E., Tsarpali, V., Efthimiou, I., Vidali, M.-S., Vlastos, D., Dailianis, S., 2013. Environmental and human risk assessment of landfill leachate: an integrated approach with the use of cytotoxic and genotoxic stress indices in mussel and human cells. J. Hazard. Mater 260, 593-601. http://dx.doi.org/10.1016/ j.jhazmat.2013.05.054.

Towett, E.K., Shepherd, K.D., Cadisch, G., 2013. Quantification of total element concentrations in soils using total X-ray fluorescence spectroscopy (TXRF). Sci. Total Environ. 463-464, 374-388. http://dx.doi.org/10.1016/ j.scitotenv.2013.05.068.

Underwood, A.J., 1979. The ecology of intertidal gastropods. In: Russell, Frederick S., Yonge, Maurice (Eds.), Advances in Marine Biology. Academic Press, pp. 111-210.

Vermeij, G., 1973. Morphological patterns in high-intertidal gastropods: adaptive strategies and their limitations. Mar. Biol. 20, 319-346.

Viarengo, A., Lowe, D., Bolognesi, C., Fabbri, E., Koehler, A., 2007. The use of biomarkers in biomonitoring: a 2-tier approach assessing the level of pollutantinduced stress syndrome in sentinel organisms. Comp. Biochem. Physiol. Part C Toxicol. Pharmacol. 146, 281-300. http://dx.doi.org/10.1016/ j.cbpc.2007.04.011.

Wade, T.L., Cantillo, A.Y., 1994. Use of standards and reference materials in the measurement of chlorinated hydrocarbon residues. Chem. Workb. Silver Spring U. S. Dep. Commer. NOAA Tech. Memo. Nos. ORCA 77.

Wang, P., Shang, H., Li, H., Wang, Y., Li, Y., Zhang, H., Zhang, Q., Liang, Y., Jiang, G., 2016. PBDEs, PCBs and PCDD/Fs in the sediments from seven major river basins in China: occurrence, congener profile and spatial tendency. Chemosphere 144, 13-20. http://dx.doi.org/10.1016/j.chemosphere.2015.08.045.

Wen, J., Pan, L., 2016. Short-term exposure to benzo[a]pyrene causes oxidative damage and affects haemolymph steroid levels in female crab Portunus trituberculatus. Environ. Pollut. 208, 486-494. http://dx.doi.org/10.1016/j.envpol.2015.10.019. Part B.

Wills, E., 1987. Evaluation of Lipid Peroxidation in Lipids and Biological Membranes, p. $285,1987$.

Yunker, M.B., Macdonald, R.W., Vingarzan, R., Mitchell, R.H., Goyette, D. Sylvestre, S., 2002. PAHs in the Fraser River basin: a critical appraisal of PAH ratios as indicators of PAH source and composition. Org. Geochem 33, 489-515. http://dx.doi.org/10.1016/S0146-6380(02)00002-5. 